\title{
COVID-19, labor demand, and government responses: evidence from job posting data
}

\author{
Xiaobing Shuai $^{1} \cdot$ Christine Chmura $^{1} \cdot$ James Stinchcomb ${ }^{1}$
}

Published online: 7 December 2020

(c) National Association for Business Economics 2020

\begin{abstract}
Using high-frequency job advertisement data, this paper evaluates dynamics among COVID-19, labor market, and government policies. We find that COVID-19 has caused a significant decline in labor demand, by as much as 30\%, measured by the number of job advertisements. But the pandemic did not result in noticeable changes in advertised wages. Regarding the roles of government policies, the study finds that the "stay-at-home" measures implemented by states appeared to suppress labor demand. The Paycheck Protection Program (PPP) program helps to stabilize the advertised wages, but also suppresses labor demand. Finally, the pandemic may increase labor demand for certain healthcare-related occupations.
\end{abstract}

Keywords COVID-19 $\cdot$ Labor demand · Government policy $\cdot$ Job advertisement

\section{Introduction}

The COVID-19 pandemic has attacked the national economy in a manner not experienced in modern times. This pandemic has impacted every community and industry in the United States. Information about the pandemic's spread, effective treatment and prevention, and government response is evolving rapidly. Consequently, any economic analysis of the pandemic should be considered preliminary. Even with this uncertainty, it is clear that this pandemic has affected the economy in significant ways.

Similarly, state and federal government actions and policies are also changing quickly, which have a profound influence on the national and regional economies. As the pandemic started to spread in the United States, in March and April of 2020, almost all states (with the exception of a few such as North and South Dakota, and Nebraska) implemented "stayat-home" orders, ${ }^{1}$ which essentially closed major components of their economies. Essential businesses such as food and agriculture, energy, and healthcare were allowed to remain open while industries such as recreation, entertainment, and restaurants were under restrictions (Mervosh et al. 2020). Since early May, many states, led by those in the south, such

Xiaobing Shuai

Xiaobing.shuai@chmuraecon.com

1 Chmura Economics \& Analytics, Richmond, USA as Georgia and Texas, started the process of reopening their economies. By late June, all states were in different phases of reopening (Mervosh et al. 2020). ${ }^{2}$

Federal actions also have had profound influences on the economy. On March 27, 2020, the U.S. Congress passed-and the President signed into law-the Coronavirus Aid, Relief, and Economic Security (CARES) Act. The CARES Act temporarily expanded unemployment insurance benefits, by offering an additional $\$ 600$ per week of pandemic unemployment compensation (PUC) to unemployed workers through the end of July 2020. The CARES Act also provided payments of up to $\$ 1200$ per person to eligible Americans. In addition, this law included the Paycheck Protection Program (PPP), which allocated $\$ 349$ billion as loans to small businesses ${ }^{3}$ to help them continue to pay their employees (Werner 2020). ${ }^{4}$ In late April, Congress passed, and the President signed another law that injected $\$ 310$ billion to replenish the PPP program. ${ }^{5}$ The

\footnotetext{
${ }^{1}$ Some states call it "shelter-in-place" orders.

2 The cut-off point for data collection is the end of June. As a result, the latest surge in infections is not captured in this paper.

${ }^{3}$ Small businesses are defined as those employing 500 or fewer people.

${ }^{4}$ This program provides forgivable loans to small businesses. The loans will be forgiven as long as they are used to cover payroll, most mortgage interest, rent, and utilities over an eight-week period and if employment and compensation levels do not decrease. Source: https ://home.treasury.gov/system/files/136/PPP--Fact-Sheet.pdf.

5 The covered period is 24 weeks beginning with the PPP loan disbursement date, or 8 weeks if borrowers received its loan before June 5, 2020. Source: U.S. Treasury.
} 
expanded unemployment benefits and PPP policies aimed to moderate the effects of the COVID-19 pandemic on the economy. As of October, Congress was continuing to consider another relief package for American people and businesses.

The impact of COVID-19 and the effectiveness of government policies have received intense interest from economists and policy makers. To contribute to this discussion, we utilize high-frequency, real-time job advertisement (posting) data to analyze the effect of the COVID-19 pandemic on key labor market indicators, such as labor demand and wage rates, during the early phases of the pandemic, namely the business lockdown and initial economic recovery period from March to June $2020 .{ }^{6}$ The real-time job advertisement data are updated daily from many online job-sites, thus providing the most timely signals of the labor market. Job ads are considered a leading indicator of employment, because businesses only place ads for jobs when they expect demand for their goods and services to grow. Once an ad is placed, it takes days if not weeks to fill the position.

While the U.S. labor market suffered massive job losses during the pandemic, we are interested to learn whether different government policies had been effective in stabilizing the labor market, particularly the PPP program and expanded unemployment benefits. We hypothesize that due to expanded unemployment compensation (PUC) offered by the CARES Act, reservation wages for those losing jobs due to the pandemic increased, pushing up market wages.

After a brief summary of existing research on COVID-19 and the labor market, we first utilize a difference-in-difference (DID) approach to examine the effect of COVID-19 on labor demand and advertised wages. We then construct an econometric model to evaluate the effect of different government policies on labor demand and wages.

We find that COVID-19 caused a significant decline in labor demand, by as much as $30 \%$, measured by the number of job advertisements. But the pandemic did not result in noticeable changes in advertised wages. The econometric analysis yields some interesting results. The lockdown measures (or "stay-at-home" orders) implemented by states appeared to suppress labor demand. The PPP program helped to stabilize advertised wages, but also suppressed labor demand. Finally, the pandemic may have increase labor demand in certain healthcare-related occupations. Those results should be of interest to policymakers and applied economists as they develop strategies to help Americans and businesses navigate this pandemic.

\footnotetext{
$\overline{6}$ The job ads are obtained from Chmura's proprietary JobsEQ soft-
} ware.

\section{Studies on COVID-19}

In the short period since COVID-19 broke out, its economic impacts have received a tremendous amount of attention, with the literature expanding daily. Some of those early papers were collected in the book Economics in the Time of Covid-19, edited by Baldwin and Mauro (2020). Those papers focused on the impact of COVID-19 on trade, global supply chains, finance and banking, and travel.

The initial research on the labor market impact of COVID-19 focused on understanding the scale and magnitude of this pandemic (Dalton 2020). In a report published in April 2020, the International Labor Organization (ILO) estimated that global working hours in the second quarter of 2020 were expected to be $10.5 \%$ lower than in the last pre-pandemic quarter. This is equivalent to 305 million fulltime jobs lost (ILO 2020). Among the most vulnerable in the labor market, almost 1.6 billion informal economy workers, such as free-lance or gig-economy workers, would be significantly impacted by government lockdown measures and consumer demand collapse (ILO 2020).

In the United States, the COVID-19 pandemic also resulted in millions of job losses. The U.S. Department of Labor reported that over 60 million workers filed for unemployment insurance from mid-March to the end of September $^{7}$. Further, the Bureau of Labor Statistics (BLS) reported that in March and April of 2020 the U.S. economy lost a total of 22.1 million jobs. ${ }^{8}$ While the monthly employment numbers rebounded, with a net gain of 11.3 million jobs from April to September, the number of individuals remaining unemployed was still 12.6 million in September (Bureau of Labor Statistics 2020). Those are job losses not seen since the Great Depression, and are directly caused by the COVID-19 pandemic (Dvorkin 2020). Using real-time data on job advertisements and weekly unemployment claims, Kahn et al. (2020) estimated a 30\% decline in online job postings across the United States.

The long-term or permanent job losses due to the pandemic are not clear. The available research is anecdotal, with conflicting results. Data from BLS and a Gallup survey suggested that roughly $80 \%$ to $85 \%$ of the layoffs in the United States could be categorized as temporary. However, by the end of May, another Gallup survey found that, though $80 \%$ of laid-off workers reported that it was very or somewhat likely that they will return to their job after the pandemic, only 3\% had actually been recalled (Rothwell 2020). Using data from previous downturns, Barrero et al. (2020) estimated that between 32 and $43 \%$ of all job losses during

\footnotetext{
${ }^{7}$ https://oui.doleta.gov/unemploy/claims_arch.asp

8 The BLS employment report measures national employment at a particular time in a month, while unemployment claims reports measure the cumulative claims filed.
} 
COVID-19 could be permanent, and one-tenth of all workdays (one-fifth for office workers) will shift from place of business to worker residence post-pandemic.

Outside the broader effects of the pandemic, some research has investigated the effect of the pandemic on certain jobs. Focusing on essential food sector workers, Cho et al. (2020) found that the pandemic significantly reduced the probability of those workers staying in industries such as food manufacturing and grocery stores. The considerable risk of infection has driven many previous food sector workers to stop working altogether. This suggests a potential labor shortage for risky occupations, which will impact wages in those industries.

Dalton (2020), using confidential employment data from BLS, investigated the effect of infection on employment at the county and industry level. The study confirmed that the greatest declines in employment were in counties with higher incidence of COVID-19. Not surprisingly, these effects varied by industry, with leisure/hospitality and other services industries having the largest declines in employment. Meanwhile, finance and insurance, a very teleworkfriendly industry, was largely unaffected by the incidence of the COVID-19 pandemic.

While there is consensus that COVID-19 has caused severe employment losses, the effects of policy seem to be mixed. So far, government "stay-at-home" or lockdown measures have received the most attention. Kahn et al. (2020) found that state "stay-at-home" measures had no effect on labor demand, while Baek et al. (2020) found 25\% of unemployment claims can be explained by the implementation of stay-at-home orders. Chetty et al. (2020) also discovered a limited impact of lockdown measures on employment. They found that individuals began changing their behavior prior to state governments issuing shutdown orders, which led them to conclude that individuals were responsive to information about the virus, even if the government did not immediately act. Recent papers on the Paycheck Protection Programs also showed mixed results. Using business survey results, one study indicated that PPP loans led to a $14-30 \%$ point increase in small business' expected survival rates, and its effect on employment was positive, but imprecise (Bartik et al. 2020). But another study did not find that PPP had a substantial effect on employment (Granja et al. 2020).

Due to the short time since the pandemic broke out, many of the papers referenced here are descriptive in nature. Our paper adds to the fast-evolving literature on COVID-19 and the labor market in several ways. First, this paper incorporates job advertisement data from May and June, while many prior studies utilized only April data. As a result, our study provides insights as the labor market climbed out of the "abyss" as states reopened their economies. In addition, with the data related to the PPP program published, this study examines the effect of this policy on the labor market, as well as state lockdown measures. We also investigated the effect of expanded unemployment benefits provided by the CARES Act. Finally, our study not only evaluates changes in the quantity of labor demand but also changes in wages.

\section{Data}

During a pandemic like COVID-19, timely data are essential for economists and policy makers. However, traditional government data on employment and consumer spending are reported monthly, while gross domestic product (GDP) is released quarterly. The unprecedented speed of changes in the labor market during the COVID-19 pandemic calls for higher frequency data than are traditionally available from government sources. While weekly initial claims for unemployment insurance collected by the Department of Labor provide information to help understand labor market developments, claims provide a partial picture because they only directly measure job destruction, not job creation.

Economists in government agencies have the advantage of gaining access to confidential firm and individual data to conduct research (Dalton 2020), but many other economists have relied on commercially available high-frequency data to analyze the impact of COVID-19. For example, Cajner $e t$ al. (2020) utilized payroll microdata from ADP, a payroll processing firm, to construct a weekly employment index to track labor market changes during the pandemic. Kahn et al. (2020) utilized job vacancy data from Burning Glass. Similarly, Chetty et al. (2020) used a range of commercial data, including credit and debit card transactions from Affinity Solution and job vacancy data from Burning Glass in their research on the impact of the pandemic.

We utilized a similar approach for this analysis with job advertisement data: Real-Time-Intelligence (RTI) from Chmura Economics \& Analytics. RTI is a job posting database that is updated daily. It collects online job advertisements from over 15,000 sources. These job advertisements are analyzed and classified into occupations, job titles, locations, certification and skill requirements, education levels, and wages, along with other relevant information. After classification, job postings are compared against each other to remove any duplicate records.

While job advertisement data are direct manifestations of labor demand for new workers, the RTI job posting data are also good indicators of overall labor market conditions in the United States. The size and trend of the RTI job posting data are closely correlated with total employment published by BLS. The correlation coefficient between monthly job postings and the official U.S. non-agricultural employment series (both seasonally adjusted) is 0.75 , significant at a 99\% confidence level. While job postings are not a perfect 
Fig. 1 Weekly Job Postings, First Half of 2019 and 2020

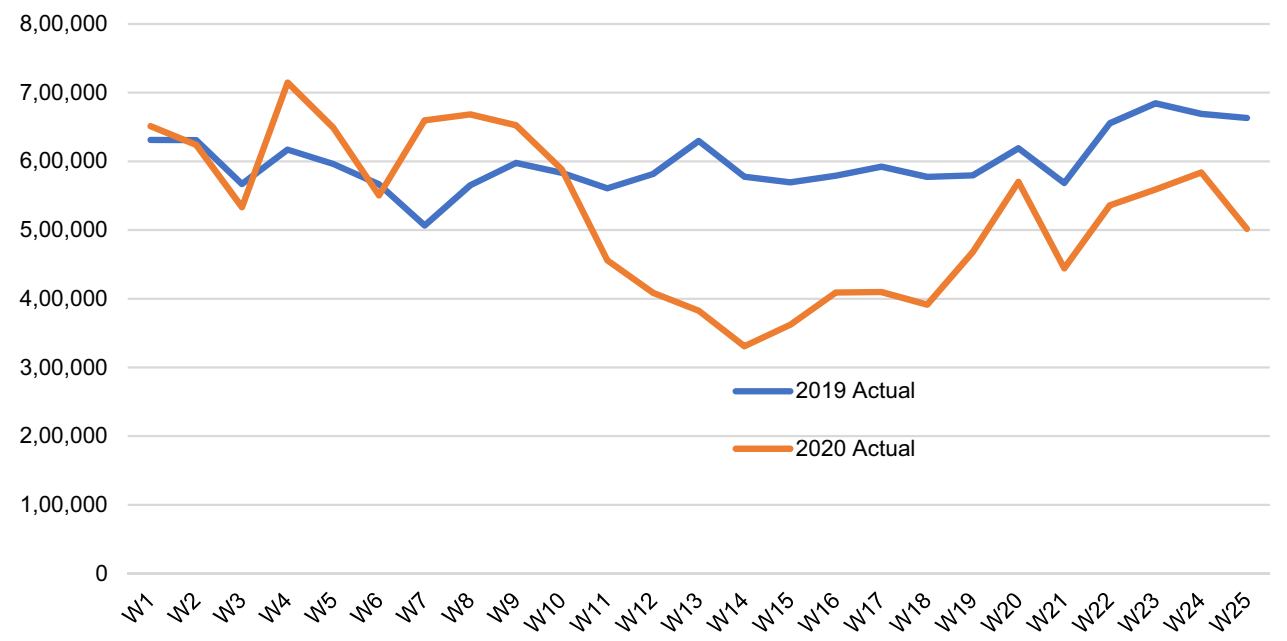

substitute for actual national employment and wages, they nevertheless are an early and timely signal of the broad labor market, especially during the COVID-19 pandemic, when market conditions change rapidly.

\section{COVID-19 effects}

Figure 1 plots weekly online job postings for the first half of 2020 (orange line), as compared with the same period for 2019 (blue line). These two series are not seasonally adjusted, showing that weekly job posting dipped for the weeks with federal holidays, specifically Martin Luther King Day, Presidents Day, and Memorial Day (in the first half of the year). Total jobs postings in the first half of 2020 were 13.1 million, roughly $12.5 \%$ lower than the 15.0 million in the first half of 2019. However, for January and February of 2020 , before the pandemic, total job postings were $7.9 \%$ higher than during the same period in 2019. In March of 2020, the COVID-19 pandemic spread quickly and many states issued "stay-at-home" orders. Job posting data started declining in early March, reaching a trough in the week of April 8 (Week 14 in Fig. 1), when most of the country was under lockdown and only essential businesses were allowed to open (Mervosh et al. 2020). ${ }^{9}$ For the week of April 8, total job postings were $50 \%$ lower than the pre-pandemic weekly average. The number of job postings started to grow in the second half of April through June, likely due to many states reopening their economies. Weekly job postings dipped in the last week of June, possibly reflecting the fact that infection numbers in many states rose again, and some states slowed their reopening. As a comparison, there was no

\footnotetext{
${ }^{9}$ Based on data from the New York Times, only the following states did not impose a "stay-at-home" order in April: Arkansas, Iowa, Nebraska, North Dakota, Oklahoma, South Dakota, and Utah.
}

decline in weekly job postings in March and April in 2019, with advertisements increasing in May and June before the summer vacation season.

For the rest of the analysis, we took a random sample of all job advertisements, totaling 200,000 observations. This represents less than $1 \%$ of total job postings in the first halves of 2019 and 2020. We classified January and February of 2020 as pre-pandemic, and March through June of 2020 as being in the pandemic.

To isolate the impact of COVID-19, we performed a difference-in-difference (DID) analysis for two key labor market indicators-job postings and advertised wages. Using job postings (JP) as an example, we first calculated the difference in this variable between the pandemic (March through June of 2020) and before the pandemic (January and February of 2020). We then compared this difference with the difference calculated for the same period of 2019. This difference-in-difference research design has been used by other studies on the effect of pandemic (Chetty et al. 2020).

More specifically, let $t$ represent the months during the pandemic (March through June), and $t-1$ represent the months before the pandemic (January and February). The change $(\Delta)$ in job postings between pandemic and pre-pandemic levels for 2020 can be expressed as:

$\Delta(\mathrm{JP})_{2020}=\frac{\operatorname{Avg}(J P)_{t}}{\operatorname{Avg}(J P)_{t-1}}$

We computed the difference in job positing for the same period last year:

$\Delta(\mathrm{JP})_{2019}=\frac{\operatorname{Avg}(J P)_{t}}{\operatorname{Avg}(J P)_{t-1}}$

The differences between above two changes, defined as the difference-in-difference (DID) in job postings, can be expressed as: 
Table 1 Impact of COVID-19 on job advertisement (sample)

\begin{tabular}{|c|c|c|c|c|c|c|c|}
\hline \multirow[t]{2}{*}{ Occupation } & \multicolumn{3}{|l|}{2020} & \multicolumn{3}{|l|}{2019} & \multirow{2}{*}{$\begin{array}{l}\text { Difference-in- } \\
\text { difference } \\
\text { Percentage point }\end{array}$} \\
\hline & Average Jan-Feb & Average Mar-June & $\%$ Change & Average Jan-Feb & Average Mar-June & $\%$ change & \\
\hline Management & 760 & 450 & 59 & 639 & 672 & 105 & -46.0 \\
\hline $\begin{array}{l}\text { Business and finan- } \\
\text { cial operations }\end{array}$ & 1103 & 694 & 63 & 1002 & 1018 & 102 & -38.7 \\
\hline $\begin{array}{l}\text { Computer and math- } \\
\text { ematical }\end{array}$ & 730 & 474 & 65 & 648 & 645 & 99 & -34.5 \\
\hline $\begin{array}{l}\text { Architecture and } \\
\text { engineering }\end{array}$ & 271 & 169 & 62 & 226 & 220 & 97 & -34.8 \\
\hline $\begin{array}{l}\text { Life, physical, and } \\
\text { social science }\end{array}$ & 307 & 194 & 63 & 264 & 275 & 104 & -40.9 \\
\hline $\begin{array}{l}\text { Community and } \\
\text { social service }\end{array}$ & 1031 & 581 & 56 & 747 & 810 & 108 & -52.1 \\
\hline Legal & 135 & 67 & 49 & 95 & 99 & 105 & -55.5 \\
\hline $\begin{array}{l}\text { Educational instruc- } \\
\text { tion and library }\end{array}$ & 694 & 316 & 46 & 1822 & 695 & 38 & 7.4 \\
\hline $\begin{array}{l}\text { Arts, design, enter- } \\
\text { tainment, sports, } \\
\text { and media }\end{array}$ & 456 & 198 & 43 & 285 & 297 & 104 & -60.6 \\
\hline $\begin{array}{l}\text { Healthcare prac- } \\
\text { titioners and } \\
\text { technical }\end{array}$ & 1111 & 680 & 61 & 498 & 557 & 112 & -50.6 \\
\hline Healthcare support & 833 & 590 & 71 & 418 & 504 & 121 & -49.7 \\
\hline Protective service & 473 & 293 & 62 & 427 & 419 & 98 & -36.0 \\
\hline $\begin{array}{l}\text { Food preparation } \\
\text { and serving related }\end{array}$ & 1337 & 889 & 67 & 926 & 1236 & 133 & -67.0 \\
\hline $\begin{array}{l}\text { Building and } \\
\text { grounds cleaning } \\
\text { and maintenance }\end{array}$ & 1003 & 800 & 80 & 853 & 1097 & 129 & -49.0 \\
\hline $\begin{array}{l}\text { Personal care and } \\
\text { service }\end{array}$ & 521 & 247 & 47 & 959 & 708 & 74 & -26.3 \\
\hline Sales and related & 1744 & 1234 & 71 & 1585 & 1663 & 105 & -34.2 \\
\hline $\begin{array}{l}\text { Office and adminis- } \\
\text { trative support }\end{array}$ & 3433 & 2202 & 64 & 3023 & 3079 & 102 & -37.7 \\
\hline $\begin{array}{l}\text { Farming, fishing, } \\
\text { and forestry }\end{array}$ & 42 & 32 & 76 & 54 & 65 & 120 & -43.6 \\
\hline $\begin{array}{l}\text { Construction and } \\
\text { extraction }\end{array}$ & 628 & 518 & 82 & 486 & 620 & 127 & -45.1 \\
\hline $\begin{array}{l}\text { Installation, mainte- } \\
\text { nance, and repair }\end{array}$ & 1227 & 831 & 68 & 842 & 1013 & 120 & -52.5 \\
\hline Production & 1123 & 922 & 82 & 951 & 1060 & 111 & -29.3 \\
\hline $\begin{array}{c}\text { Transportation and } \\
\text { material moving }\end{array}$ & 2247 & 2016 & 90 & 2073 & 2068 & 100 & -10.0 \\
\hline Total & 21,210 & 14,395 & 68 & 18,826 & 18,819 & 100 & -32.1 \\
\hline
\end{tabular}

Source JobsEQ RTI

$\mathrm{DID}(\mathrm{JP})=\Delta(\mathrm{JP})_{2020}-\Delta(\mathrm{JP})_{2019}$

The difference-in-difference for advertised wages were computed in the same fashion.

\subsection{Labor demand}

We first evaluated DID in job postings to understand the effect of COVID-19 on labor demand (Table 1). In our 
sample, the average monthly job postings were 21,210 in 2020 before the pandemic, which declined by $32 \%$ to 14,395 during the pandemic. In 2019, the monthly job postings in the first two months averaged 18,826 , which was virtually equal to the average of 18,819 from March to June. The difference-in-difference for job postings is estimated to be 32.1 percentage points, representing a significant deterioration in labor demand. This number is consistent with the study using Burning Glass job advertisements, where Kahn et al. (2020) estimated a 30\% decline in online job postings across the United States during the pandemic.

The job posting data for major occupations confirmed the expectation that certain jobs are affected more by the pandemic than others. During the pandemic when the "stayat-home" orders were in effect in many states, only essential businesses were allowed to open, which included grocery stores, healthcare, utility, and some manufacturing. Many non-essential retail stores, food services establishments, personal services, and entertainment businesses were either closed or under severe restrictions.

Table 1 shows that the occupations impacted the most, according to the difference-in-difference estimate, were those in food preparation and serving, with a DID value of 67.0 percentage points. While the number of job advertisements for these occupations declined by $33 \%$ in 2020, job postings for the same period in 2019 rose 33\%. Occupations in arts, design, entertainment, sports media and media were also impacted significantly, with a DID measure of 60.6 percentage points.

On the positive side, occupations that are out-doors, and for which it is easy to maintain social distance, were less affected, compared to jobs that are in-doors and require face-to-face interactions. For example, transportation and material moving occupations experienced a relatively mild decline (DID of 10.0 percentage points) in labor demand, reflecting the trend that many consumers shifted to online shopping during the pandemic, increasing demand for transportation and delivery workers. Similarly, production workers did relatively better during the pandemic. In 2020, monthly job postings for those workers decreased by $20 \%$. Yet last year, monthly job advertisements increased by $11 \%$ for the same period. The DID for this occupation group is - 29.3 percentage points, better than most occupations. Many manufacturing businesses were classified as essential, and it is often relatively easy to keep social distancing. ${ }^{10}$

\footnotetext{
${ }_{10}$ Please note that there was an unusually large number of job postings in education in early 2019, which caused the COVID-19 effect to be positive. We think this is a data anomaly. Similarly, there might have been weather-related decreases in job advertisement for construction workers, reflecting the exceptionally warm weather in early 2020 then boosting construction; but the main driver for the DID measure is surely COVID-19.
}

Studies have found that jobs in professional services were less impacted by the pandemic, as workers can easily work remotely. While that was true for overall employment and revenues (Chetty et al. 2020), our analysis indicates labor demand for those workers deteriorated significantly during the pandemic. As Table 1 shows, the DID for professional occupations, such as business and finance, and computer and mathematics, were slightly higher than that for all occupations.

\subsection{Advertised wages}

Comparing the changes in advertised wages reveals that the COVID-19 pandemic did not negatively impact wages. ${ }^{11}$ As Table 2 shows, the average advertised wage for all jobs in January and February of 2020 was $\$ 42,241$, while advertised wages during the pandemic (March through June of 2020 ) averaged $\$ 42,372$. As a comparison, in 2019 , the average wage for job postings in January and February was $\$ 40,932$, while that for April through June was $\$ 39,951$. The difference-in-difference measure of advertised wages implies a positive effect of 3.7 percentage points from the COVID-19 pandemic. Similar results have been reported by other studies that tracked real-time labor market data. For example, Chetty et al. (2020) found that wage rates remained unchanged through the COVID-19 pandemic for those workers who retained their jobs.

Examining DID different occupations, wages offered during the pandemic were consistently at the same level of, or higher than pre-pandemic wages for a majority. The noticeable exception is transportation and material moving occupations, for which the pandemic appears to have decreased advertised wages. ${ }^{12}$ For sales and related, and healthcare practitioner and technical occupations, the pandemic appears to have had a positive effect on advertised wages, possibly due to the risk premium of working in businesses with a high risk of exposure to the virus.

Economic theories might indicate that millions of job losses and surging unemployment during the COVID-19 pandemic would have put downward pressure on wages. This does not appear to have been the case. One hypothesis can be attributed to the risk premium. COVID-19 is a highly infectious disease that can lead to hospitalization and death for some victims. When the safest measure of being healthy is staying at home, it may require extra effort for businesses to entice people to work, especially for those in essential industries that have contact with the public. During

\footnotetext{
11 Please note that only a portion of job advertisements provided information of wages offered.

12 Please note that DID for wage in education is also negative. There were an unusually large number of job postings in education in early 2019. We think this was a data anomaly.
} 
Table 2 Impact of COVID-19 on advertised wages (sample)

\begin{tabular}{|c|c|c|c|c|c|c|c|}
\hline \multirow[t]{2}{*}{ Occupation } & \multicolumn{3}{|l|}{2020} & \multicolumn{3}{|l|}{2019} & \multirow{2}{*}{$\begin{array}{l}\text { Difference-in- } \\
\text { difference } \\
\text { Percentage point }\end{array}$} \\
\hline & Average Jan-Feb & Average Mar-June & $\%$ Change & Average Jan-Feb & Average Mar-June & $\%$ Change & \\
\hline Management & 58,718 & 60,536 & 103 & 62,407 & 59,941 & 96 & 7.0 \\
\hline $\begin{array}{l}\text { Business and finan- } \\
\text { cial operations }\end{array}$ & 57,904 & 58,645 & 101 & 56,046 & 55,371 & 99 & 2.5 \\
\hline $\begin{array}{l}\text { Computer and } \\
\text { mathematical }\end{array}$ & 72,861 & 77,159 & 106 & 77,699 & 72,407 & 93 & 12.7 \\
\hline $\begin{array}{l}\text { Architecture and } \\
\text { engineering }\end{array}$ & 60,137 & 63,545 & 106 & 59,944 & 62,660 & 105 & 1.1 \\
\hline $\begin{array}{l}\text { Life, physical, and } \\
\text { social science }\end{array}$ & 49,774 & 54,178 & 109 & 46,397 & 49,137 & 106 & 2.9 \\
\hline $\begin{array}{l}\text { Community and } \\
\text { social service }\end{array}$ & 38,928 & 41,157 & 106 & 38,128 & 37,706 & 99 & 6.8 \\
\hline Legal & 52,509 & 54,161 & 103 & 62,846 & 53,089 & 84 & 18.7 \\
\hline $\begin{array}{l}\text { Educational instruc- } \\
\text { tion and library }\end{array}$ & 38,525 & 37,441 & 97 & 32,338 & 36,542 & 113 & -15.8 \\
\hline $\begin{array}{l}\text { Arts, design, enter- } \\
\text { tainment, sports, } \\
\text { and media }\end{array}$ & 39,437 & 35,653 & 90 & 41,634 & 39,260 & 94 & -3.9 \\
\hline $\begin{array}{l}\text { Healthcare prac- } \\
\text { titioners and } \\
\text { technical }\end{array}$ & 59,425 & 63,531 & 107 & 67,100 & 56,870 & 85 & 22.2 \\
\hline Healthcare support & 31,420 & 30,233 & 96 & 32,496 & 28,324 & 87 & 9.1 \\
\hline Protective service & 37,651 & 37,650 & 100 & 35,455 & 37,064 & 105 & -4.5 \\
\hline $\begin{array}{l}\text { Food prepara- } \\
\text { tion and serving } \\
\text { related }\end{array}$ & 25,453 & 25,518 & 100 & 25,714 & 25,303 & 98 & 1.9 \\
\hline $\begin{array}{l}\text { Building and } \\
\text { grounds cleaning } \\
\text { and maintenance }\end{array}$ & 27,929 & 28,998 & 104 & 31,139 & 27,650 & 89 & 15.0 \\
\hline $\begin{array}{l}\text { Personal care and } \\
\text { service }\end{array}$ & 32,233 & 33,236 & 103 & 28,167 & 29,010 & 103 & 0.1 \\
\hline Sales and related & 50,684 & 53,742 & 106 & 51,801 & 46,303 & 89 & 16.6 \\
\hline $\begin{array}{l}\text { Office and adminis- } \\
\text { trative support }\end{array}$ & 34,434 & 35,545 & 103 & 35,456 & 34,236 & 97 & 6.7 \\
\hline $\begin{array}{l}\text { Farming, fishing, } \\
\text { and forestry }\end{array}$ & 29,589 & 30,098 & 102 & 27,094 & 30,667 & 113 & -11.5 \\
\hline $\begin{array}{l}\text { Construction and } \\
\text { extraction }\end{array}$ & 43,509 & 44,357 & 102 & 41,065 & 39,814 & 97 & 5.0 \\
\hline $\begin{array}{l}\text { Installation, mainte- } \\
\text { nance, and repair }\end{array}$ & 43,113 & 44,214 & 103 & 43,580 & 40,900 & 94 & 8.7 \\
\hline Production & 32,591 & 32,227 & 99 & 32,312 & 31,529 & 98 & 1.3 \\
\hline $\begin{array}{c}\text { Transportation and } \\
\text { material moving }\end{array}$ & 43,243 & 38,045 & 88 & 36,351 & 35,420 & 97 & -9.5 \\
\hline Total & 42,241 & 42,372 & 100 & 40,932 & 39,551 & 97 & 3.7 \\
\hline
\end{tabular}

Source JobsEQ RTI

the pandemic, many businesses in retail and delivery implemented pandemic or hazardous pay, typically in the form of a $10 \%$ to $20 \%$ increase in wages. This practice contributed to the elevated advertised wages for those occupations during the pandemic (Corkery 2020). Our data in Table 2 showed sales and healthcare occupations had the largest positive DID wage in job ads. However, some companies have been ending the hazardous pay premium. ${ }^{13}$ It will be interesting to track whether removing this extra pay will reduce advertised wages.

\footnotetext{
${ }^{13}$ Examples include Target, Walmart, CVS, Whole Foods, Costco, Sprouts, Kroger, and Starbucks, where hazardous pay ended in May. Source: https://www.latimes.com/business/story/2020-05-13/starbucksgave-its-employees-a-reprieve-amid-the-pandemic-thats-ending-now
} 
Fig. 2 DID in job posting by states

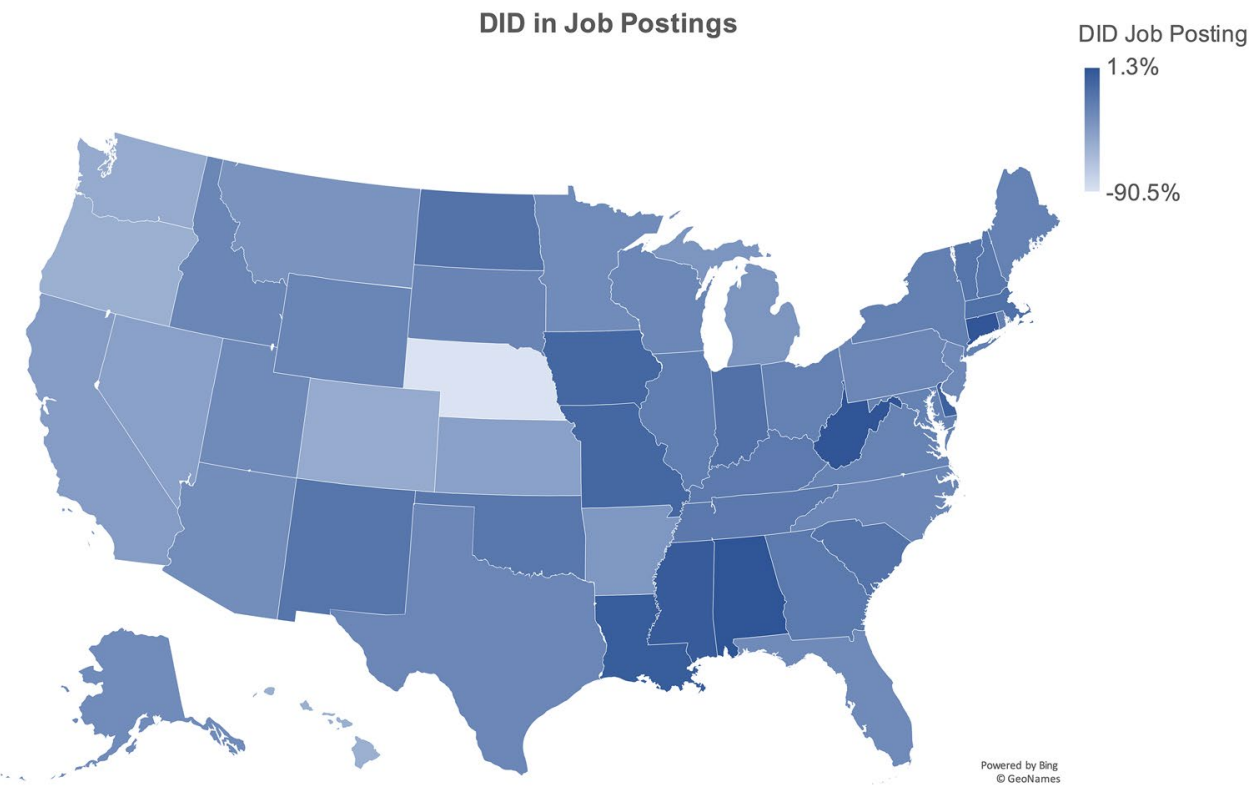

Another hypothesis related to elevated wages could be government policies, such as expanded unemployment benefits and PPP programs provided by the CARES Act. This law provided extra benefits to individuals who lost their jobs due to COVID-19. In addition to normal weekly state-average unemployment benefits, averaging \$386 in February 2020 (U.S. Department of Labor 2020), the CARES Act provided an additional $\$ 600$ per week for four months. Without pandemic unemployment compensation (PUC), the national average unemployment benefit is equivalent to an annual wage of $\$ 20,107$. With PUC, the UE benefits translate to an equivalent annual wage of $\$ 51,272$, higher than prevailing wages for many food service, sales, and healthcare support occupations. This extra benefit may have provided the incentive for unemployed individuals in low-paying jobs to forgo seeking employment temporarily, thus offsetting the downward pressure on wages exerted due to massive job losses. Since the extra PUC benefit expired at the end of July 2020, it will be interesting to see whether wages associated with job postings started to drop, especially for those low-wage occupations. Similarly, the PPP program may also help maintain wages, as some potentially laid-off workers were kept on business payrolls.

\section{Effect of government policies}

\subsection{Model}

We performed an econometric analysis to examine the effect of various government policies, along with variables related to COVID-19 infections, on labor demand and wages. In these regressions, the dependent variables are state-level job postings and advertised wages, measured in difference-in-difference values from 2019 to 2020, using the formula calculated in the previous section. The analysis was performed at the state level because there are significant differences in state-varying policies, such as lockdown and reopening schedules. Since the focus is to evaluate how the COVID-19 pandemic and policy measures affect the labor market, applying DID treatment to labor demand and wages enables us to eliminate the need to control many observed and unobserved variables that are common either across states or within states. This approach has been used frequently in COVID-19-related literature (Dalton 2020; Chetty et al. 2020). In addition, using DID measures can remove any time-specific fixed impact, especially the seasonality that may affect labor demand and wages. Figures 2 and 3 summarize the DID in job postings and advertised wages by states.

Let JP represent job postings, and W represent advertised wages. We estimated the following two linear models:

$$
\begin{aligned}
D I D(J P)= & \beta 0+\beta 1 * I R+\beta 2 * D R+\beta 3 * \text { Duration } \\
& +\beta 4 * U E+\beta 5 * P P P+\beta 6 * \text { Ind }+\varepsilon \\
D I D(W)= & \gamma 0+\gamma 1 * I R+\gamma 2 * D R+\gamma 3 * \text { Duration } \\
& +r 4 * U E+r 5 * P P P+r 6 * \text { Ind }+\eta
\end{aligned}
$$

For independent variables, two COVID-19 diseaserelated variables were used. ${ }^{14}$ The first is the infection rate per 1000 residents $(I R)$ for each state. The second is the death rate $(D R)$, measured as the percentage of deaths in total infections for each state. It is hypothesized that the higher the infection rate, the less willing consumers are to

\footnotetext{
${ }^{14}$ The Appendix provides a summary of COVID-19-related independent variables.
} 
Fig. 3 DID in advertised wages by states
DID in Advertised Wages

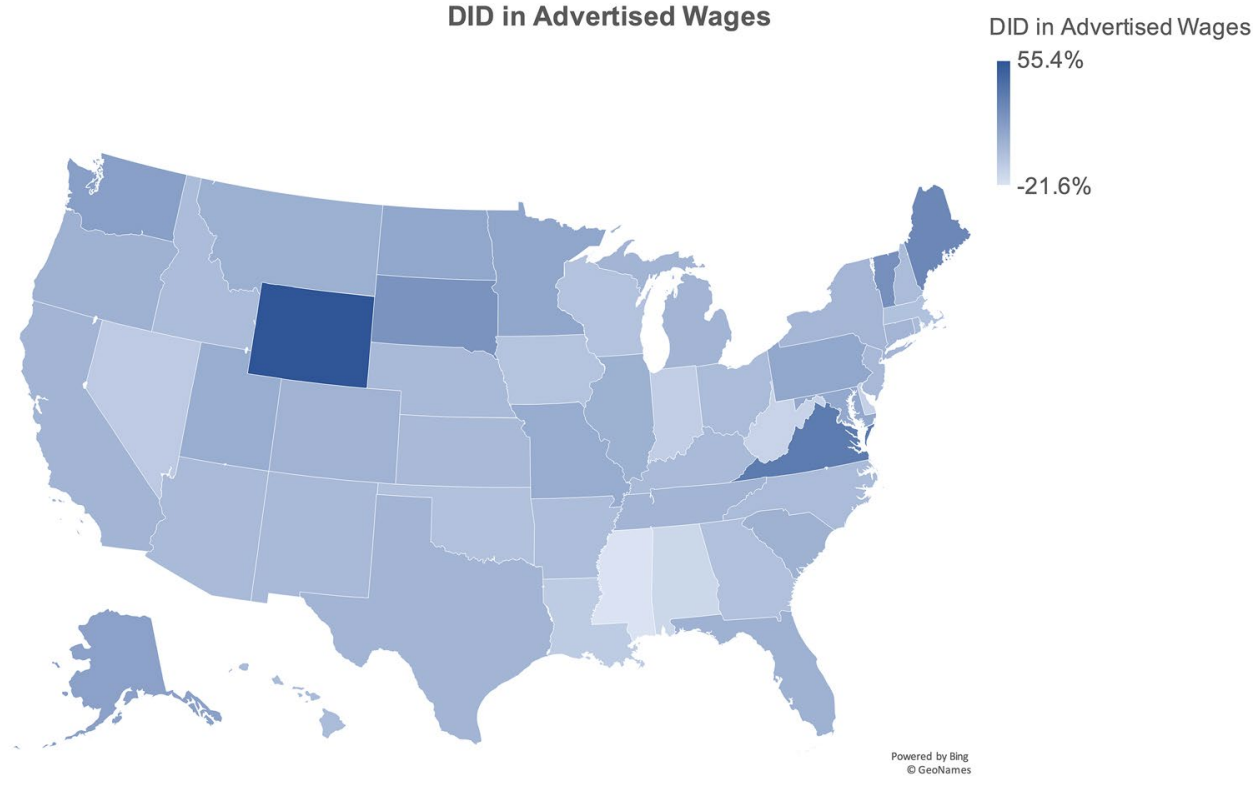

patronize businesses, thus reducing labor demand during the pandemic. The COVID-19 death rate is also included, as it is hypothesized that this variable is a better measure than general infection rates of the demand for healthcare resources such as healthcare workers and medical supplies. Both infection and death rates are cumulative values at the end of June 2020, retrieved from a database maintained by the New York Times (Mervosh et al. 2020).

For state policy variables, we included the duration of "stay-at-home" orders, measured as the number of days for which each state is in lockdown (Duration). The hypothesis is that the longer a state was under lockdown, the lower the level of labor demand. In mid-to-late March, except for a few states such as North and South Dakota, most issued "stay-athome" or "shelter-in-place" orders. Those measures resulted in the closure of many non-essential businesses. One month later, some states, led by those in the south, such as Texas and Georgia, started loosening restrictions and reopening their economies. By late June, most states were in different stages of reopening, even in hard-hit New York and New Jersey. ${ }^{15}$ The information on the starting and ending dates of "stay-at-home" orders was retrieved from a database maintained by the New York Times (Mervosh et al. 2020). ${ }^{16}$

The expanded unemployment benefit-Pandemic Unemployment Compensation (PUC) — provided by the CARES Act may have created a disincentive for individuals to work. The expanded PUC, plus typical unemployment insurance benefits, were higher than prevailing wages for many

\footnotetext{
15 In the summer of 2020, inflections in U.S. rose again, and states began considering additional restrictions. Those data are not available for this version of the paper.

${ }^{16}$ For states with different phases of reopening, we used the date of initial reopening to calculate the duration of lockdown.
}

low-paying but essential jobs, such as those in grocery stores, healthcare assistance, and food services. While labor economics theory indicates that the PUC would have, other things equal, decreased labor supply, how that would have translated into labor demand is uncertain. It is hypothesized that such a program may help maintain wages. The data utilized in this analysis $(U E)$ was monthly unemployment benefits during the pandemic, retrieved from the U.S. Department of Labor ${ }^{17}$.

The paycheck protection program may affect labor demand as well. PPP aimed to help businesses pay two months of payroll so that they don't layoff their employees. In addition, already laid-off workers can be recalled. While this policy, in theory, would have been assumed to help businesses avoid layoffs, thus lessening the degree of job destruction, its effect on new job demand is not clear. But we expect that this program may have helped to maintain wage levels. The PPP data by state were from the U.S. Small Business Administration (U.S. Small Business Administration 2020). We calculated the per capita PPP amount for each state by dividing the total PPP loan amount by the state's population.

We did not include the household stimulus check in the model. While some studies found this policy played an important role in maintaining household spending and possibly saved jobs (Chetty et al. 2020), we excluded it due to a technicality. On a per capita basis, there is very little variation among states in terms of the stimulus check amount, making it highly correlated with the intercept of the model. As a result, the model was not able to identify its effect when this variable was included.

Finally, the COVID-19 pandemic has struck different industries unevenly. To capture those effects, we included

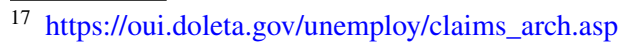


Table 3 Regression results

\begin{tabular}{|c|c|c|c|c|}
\hline & \multicolumn{2}{|l|}{ DID in job postings } & \multicolumn{2}{|c|}{ DID in advertised wages } \\
\hline & Coefficient estimate & $P$-value & Coefficient estimate & $P$-value \\
\hline Intercept & -0.0210 & 0.951 & -0.3411 & 0.215 \\
\hline Infection rates (IR) & 0.0014 & 0.820 & -0.0086 & 0.088 \\
\hline Death rate (DR) & 3.1326 & 0.048 & -0.8678 & 0.488 \\
\hline Lockdown duration & -0.0018 & 0.146 & -0.0005 & 0.670 \\
\hline PPP amt per capita (PPP) & -0.0001 & 0.101 & 0.0001 & 0.054 \\
\hline Unemployment benefit (UE) & -0.0005 & 0.142 & 0.0002 & 0.410 \\
\hline Leisure (Ind1) & -0.2632 & 0.788 & -0.3019 & 0.702 \\
\hline Health (Ind2) & 2.3902 & 0.071 & 0.7643 & 0.466 \\
\hline Number of observations & 51 & & 51 & \\
\hline R-square & 0.3698 & & 0.2300 & \\
\hline BP test (chi-square) & 7.9359 & & 3.4172 & \\
\hline
\end{tabular}

two variables (Ind) measuring the industry mix for each state; specifically, the percentage of workers in leisure and healthcare sectors. Due to the small number of observations in these regressions (51), we were not able to include variables for all major industry sectors.

Several diagnostic tests were run to ensure that the model specification and estimating methods were justified. First, multicollinearity among independent variables was not a serious concern. The variable inflation factor (VIF) for each independent variable was calculated. Though there is no deterministic criterion for VIF, a rule of thumb is that a VIF value greater than 5 for an independent variable indicates possible high correlation between it and other independent variables. All independent variables in our model have VIF values ranging from 1.3 to 2.3 .

In a cross-sectional model, heteroskedasticity is a concern. We performed a Breusch-Pagan test for heteroskedasticity for both regression models. The resulting $\chi^{2}$ values are 7.93 and 3.43, with $P$-values of 0.34 and 0.84 . These tests imply that we cannot reject the hypothesis of the homogeneity of error terms at $95 \%$ significance level. The specification tests indicate that ordinary least squares (OLS) method is appropriate to estimate the two models.

\subsection{Effects on labor demand}

Table 3 presents the results from the OLS regressions, with dependent variables being state-level DID in job postings and advertised wages. Since we have only state-wide data, the total number of observations is 51 . Possibly due to the small sample size, in both equations only a few variables are significant at a $95 \%$ or $90 \%$ confidence level. The overall explanatory power of those two models, measured by $R^{2}$, is 0.37 and 0.23 , respectively.

For the labor demand model, the results regarding two COVID-19-related variables are a little surprising. The model shows that the infection rate had no effect, but the death rate has a positive and significant association with DID in job postings. Anecdotal evidence suggests that in places with higher degrees of infections, residents were afraid to go out and patronize businesses, which should have reduced labor demand. Studies such as Dvorkin (2020) and Dalton (2020) found infection levels affected job losses. It is likely that our model captures the effects of reopenings in June, which could mitigate the effect of infection rates, while other studies included only April data,

The positive and significant coefficient on the death rate suggests that states with relatively higher death rates experienced lower levels of labor demand deterioration during the pandemic. The possible explanation is that in areas with a large number of deaths due to COVID-19, there are more seriously ill patients. Those seriously ill patients created intensive demand for healthcare resources, including nurses, nurse assistants, and other healthcare professionals. For example, during the early phase of the pandemic, there were calls for volunteer healthcare and related workers to the New York area (City of New York 2020). There was also demand for workers to construct temporary field hospitals and other facilities in areas with large numbers of seriously ill patients. In addition, individuals were needed to prepare meals or deliver food and other necessities. As a result, the anomalous death rate coefficient may proxy for an increased demand for resources that muted the anticipated signal of labor demand deterioration.

We believe that the model suggests that the duration of lockdown may have had a negative impact on labor demand. This variable is not statistically significant, with a $P$-value of 0.15 , but the implication of the negative value is clear. States without "stay-at-home" orders or those with a shorter lockdown period were concentrated in interior west and southern states, including North and South Dakota, Wyoming, and Nebraska, while states with longer lockdown periods include New York, New Jersey, Illinois, and Washington 
(See the Appendix). We feel that the model indicates that job advertisements either declined less or rebounded earlier in states with shorter lockdown durations. Our belief is different from the results of other studies. For example Chetty et al. (2020) found limited evidence on the effect of state ordered lockdowns. It is possible that this is due to their study being based on data up to April, when most states were under lockdown. The effect of such a policy cannot then be identified as variable values for most states would be similar. However, there were sizable variations in terms of timing at which states exited lockdown, and those variables allow us to identify what we believe are some negative effects of this policy, even though the regression results do not show statistical insignificance.

We also found that the per capita PPP amount had a negative correlation with DID of job advertisements. This variable is moderately significant, at a $90 \%$ level. It suggests that the PPP did not lead to more job openings. In fact, PPP appeared to have suppressed labor demand. This result is counter-intuitive at first glance, but other studies also found mixed results on this program. For example, Chetty et al. (2020) concluded that the PPP program had little material impact on employment at small businesses, which contradicedt the original purpose of the program. One possible explanation is the free-rider issue inherent in the design of the program. The PPP program was open to all businesses with employment below 500, regardless of how severely they were impacted by COVID-19, and the loans can also be forgiven. It is possible that many businesses received such loans that did not intend to immediately lay off workers. If this program only helped a small number of businesses truly in need over the short run, those positive effects could have been overshadowed by many businesses who may not have needed the funds during our study period. In addition, the PPP program may have delayed businesses reopening in May and June, as the loan could have kept businesses afloat while remaining closed, thus reducing the demand for labor even as the economy started reopening. Finally, since only smaller businesses are allowed to apply for PPP, and they may have been harder hit by the pandemic, the negative correlation between PPP and labor demand may reflect that association. $^{18}$

We also believe that expanded unemployment benefits had a negative impact on labor demand, even though the coefficient was not statistically significant, with a $P$-value of $14 \%$. Economic theory is clear that this benefit would have increased individuals' reservation wages, thus dampening

\footnotetext{
18 The job posting data we have do not have data related to firm size. Of course, the reality is that firms employing several hundred workers would not ordinarily be seen as "small" but were eligible for PPP assistance.
}

the supply of labor. However, the negative point value of the coefficient estimate suggest to us this effect was transferred to labor demand and job formation as well. Businesses in states with high unemployment benefits may have anticipated reluctance by job seekers to accept offers and so delayed hiring during the pandemic. With this benefit expiring at the end of July, it will be noteworthy to track whether there were increases in labor demand for jobs whose prevailing wages are lower than the expanded unemployment benefit.

Finally, we controlled for two industry mix variables, as studies have shown that the COVID-19 pandemic affects industries unevenly. One industry variable that is positive and significant at $90 \%$ confidence level is the percentage of state workers in healthcare. The model shows that states with higher concentration of healthcare workers experienced less labor demand deterioration. While the absolute number of job advertisements for healthcare workers fell rather sharply, compared with other industries, hospitals and other healthcare facilities still had demand for workers to handle testing and care for COVID-19 patients. Also, healthcare workers are more likely to be in contact with COVID-19 patients and have a higher risk of contracting the virus. When they do, and need to be quarantined, there are additional needs for their replacements, thus boosting labor demand.

On the other hand, many leisure sector businesses, such as recreation, entertainment, and restaurants, were ordered to close during the pandemic when "stay-at-home" orders were in effect. As a result, it was expected that states with high concentrations of leisure workers like Hawaii or Nevada would experience a sharp drop in job postings. Our model shows that the concentration of leisure workers has a negative correlation with DID in job posting, according to the point estimate, but this coefficient estimate is not statistically significant.

\subsection{Effects on advertised wage}

Examining the regression results on advertised wages, the most significant impact on DID in wages is the per capita PPP amount for each state. This variable is positive and significant at the $90 \%$ level. The implication is that with the billions of dollars of PPP distributed, this policy effectively maintained wage levels. For individuals that would otherwise be laid off, this program prevented them from being jobless for at least 2 months. Even for businesses which have no plans to reduce their staff levels but received PPP loans, they may feel less pressure to resort to a pay cut or reduce staff hours to weather the pandemic shock.

In theory, expanded unemployment benefits (PUC) provided by the CARES Act should have helped wage levels. The additional pandemic pay may have provided incentives for unemployed individuals not to seek employment. This effectively suppresses labor supply and offsets the downward 
pressure on wages due to massive job losses. The coefficient estimate for this variable is positive, as expected, but not statistically significant.

Infection rates are the other significant variable in the wage regression. The coefficient estimate shows that this variable has a negative association with DID in wages, significant at the $90 \%$ confidence level. One possible explanation for the negative sign is that while overall labor demand during the pandemic was not affected by infection rates, the composition of jobs may have changed. Many essential jobs needed during the pandemic, such as grocery, delivery, or healthcare support, were low-wage; that may have brought the overall advertised wage down.

All other variables in this regression are not significant, including lockdown duration and death rates. Furthermore, the industry mix variables generally do not have any effect on DID in advertised wages. In theory, due to the heightened risks during the pandemic, it is hypothesized that industries employing more essential workers needed to offer higher wages to incentivize people to fill those jobs. However, our model did not detect such an impact, possibly due to the fact that essential jobs were still relatively few in total job advertisements; and thus not able to greatly affect average market wages for each state.

\section{Conclusion}

In summary, the COVID-19 pandemic caused enormous disruptions in the U.S. labor market. Job posting data shows that the pandemic resulted in a $30 \%$ decline in labor demand, as compared with the same period a year ago. But advertised wages appeared to hold firm.

The analysis also suggests that the infection rates itself did not impact labor demand; but death rates, a representation of the magnitude of severely ill patients, apparently generated demands for labor resources. For government policies, the PPP program played an important role in stabilizing market wages, but it also appears to be associated with weaker labor demand. The lockdown measures also suppressed labor demand, but the result is less significant. Similarly, the disincentive provided by the expanded unemployment benefits may also have affected labor demand.

This paper adds to the fast-evolving literature on COVID-19 and its impact on the labor market, and can lead to more future research. Using high-frequency job posting data through the reopening period, we were able to identify the effects of some policies that were not discovered in other studies. In addition, our study not only evaluated the changes in the number of job postings but also the changes in wage rates.

The limitation of this study is that it only addresses the short-term impact of the COVID-19 pandemic on the U.S. labor market. The situation remains fluid. The findings of this study may change as new data be available, and it also calls for continued research and updates using the latest labor market data.

\section{Appendix}

See Table 4. 
Table 4 Impact of COVID-19 on job advertisement (sample)

\begin{tabular}{lllll}
\hline & Mean & Standard Deviation & Minimum Value & Maximum Value \\
\hline DID in job postings & $-29.52 \%$ & $17.38 \%$ & $-90.46 \%$ & $1.33 \%$ \\
DID in advertised wages & $3.48 \%$ & $12.65 \%$ & $-21.56 \%$ & $55.42 \%$ \\
Infection rates (IR) & 6.31 & 4.52 & 0.56 & 20.11 \\
Death rate (DR) & $4.00 \%$ & $2.09 \%$ & $0.91 \%$ & $9.30 \%$ \\
Lockdown duration & 36.75 & 20.93 & 0.00 & 79.00 \\
PPP amt per capita (PPP) & $\$ 1,613.49$ & $\$ 352.00$ & $\$ 997.23$ & $\$ 3,043.34$ \\
Unemployment benefit (UE) & $\$ 965.53$ & $\$ 81.33$ & $\$ 814.71$ & $\$ 1,149.63$ \\
Pct of leisure employment & $11.33 \%$ & $2.46 \%$ & $9.03 \%$ & $24.37 \%$ \\
Pct of health employment & $14.49 \%$ & $1.97 \%$ & $9.50 \%$ & $18.97 \%$ \\
\hline
\end{tabular}

\section{Reference}

Baek, ChaeWon, Peter B, McCrory, Todd, Messer, and Preston, Mui. 2020. Unemployment Effects of Stay-at-Home Orders: Evidence from High Frequency Claims Data. IRLE Working Paper \#101-20. Institute for Research on Labor and Employment, University of California-Berkley. https://irle.berkeley.edu/files/2020/04/Unemp loyment-Effects-of-Stay-at-Home-Orders.pdf.

Baldwin, Richard, Beatrice Weder, and di Mauro (eds.). 2020. Economics in the Times of COVID-19. London: CEPR Press.

Barrero, Jose Maria, Nick, Bloom, and Steven J, Davis. 2020. COVID19 is also a Reallocation Shock. No. 2020-59. Becker Friedman Institute, University of Chicago. https://bfi.uchicago.edu/wp-conte nt/uploads/BFI_WP_202059.pdf.

Bartik, Alexander, Zoe Cullen, Edward, Glaeser, Michael, Luca, Christopher, Stanton, and Adi, Sunderam. 2020. The Targeting and Impact of Paycheck Protection Program Loans to Small Business. Working Paper No. 27623, National Bureau of Economic Research. https://www.nber.org/system/files/working_papers/ w27623/w27623.pdf.

Bureau of Labor Statistics. 2020. Employment Situation - September 2020. USDL-20-1838. https://www.bls.gov/news.release/empsi t.nr0.htm.

Cajner, Tomaz, Leland D. Crane, Ryan A. Decker, Adrian, HaminsPuertolas, and Christopher, Kurz. 2020. Tracking Labor Market Developments during the COVID-19 Pandemic: A Preliminary Assessment. Finance and Economics Discussion Series 2020-30. Federal Reserve Board. https://www.federalreserve.gov/econres/ feds/files/2020030pap.pdf.

Chetty, Raj, John N. Friedman, Nathaniel, Hendren, and Michael, Stepner. 2020. How Did COVID-19 and Stabilization Policies Affect Spending and Employment? A New Real-Time Economic Tracker Based on Private Sector Data. Harvard Kennedy School. https:// www.hks.harvard.edu/centers/mrcbg/programs/growthpolicy/realtime-economics-new-platform-track-impacts-covid-19-people.

Cho, Seung Jin, Jun, Yeong Lee, and John V. Winters. 2020. COVID19 Employment Status Impacts on Food Sector Workers. IZA DP No. 13334. Discussion Paper Series. IZA Institute of Labor Economics.

City of New York. 2020. New Yorkers Find Ways to Help Those in Need During COVID-19 Pandemic. June 15. https://www1.nyc.gov/site/ em/about/press-releases/20200615_pr_nycem-volunteer\%20coo rdination-task-force.page.

Corkery, Michael. 2020. Hero' Pay Raises Disappear for Many Essential Workers. The New York Times, July 14. https://www.nytim es.com/2020/07/14/business/coronavirus-essential-workers-payraises.html.
Dalton, Michael. 2020. Labor Market Effects of Local Spread of COVID-19. Working Paper 524. Bureau of Labor Statistics. https ://www.bls.gov/osmr/research-papers/2020/pdf/ec200060.pdf.

Dvorkin, Maximiliano. 2020. The Impact of COVID-19 on Labor Markets across the U.S. Federal Reserve Bank of St. Louis. https:// www.stlouisfed.org/on-the-economy/2020/april/impact-covid-19labor-markets-us?print=true.

Granja, Joao, Christos, Makridis, Constantine, Yannelis, and Eric, Zwick. 2020. Did the Paycheck Protection Program Hit the Target? NBER Working Paper No. 27095. Cambridge, MA: National Bureau of Economic Research.

International Labor Organization. 2020. ILO Monitor: COVID-19 and the Workd of Work, Third Edition.

Kahn, Lisa, Fabian, Lange, and David, Wiczer. 2020. Labor Demand in the Time of COVID-19: Evidence from Vacancy Postings and UI Claims. Working paper 27061, National Bureau of Economic Research. https://doi.org/10.3386/w27061.

Mervosh, Sarah, Jasmine Lee, Lazaro Gamio, and Nadia Popovich. 2020. See How All 50 States Are Reopening. New York Times, June 18. https://www.nytimes.com/interactive/2020/us/state s-reopen-map-coronavirus.html.

New York Times. 2020. Coronavirus in the U.S.: Latest Map and Case Count. https://www.nytimes.com/interactive/2020/us/coronaviru s-us-cases.html.

Rothwell, Jonathan. 2020. The Effects of COVID-19 on International Labor Markets: An Update. Brookings Institution. https://www. brookings.edu/research/the-effects-of-covid-19-on-internationallabor-markets-an-update/.

U.S. Small Business Administration. 2020. Paycheck Protection Program Report through June 30, 2020. https://www.sba.gov/ document/technote-paycheck-protection-program-report-throu gh-june-30-2020.

Werner, Erica. 2020. Senate Approves \$2.2 Trillion Coronavirus Bill Aimed at Slowing Economic Free Fall. Washington Post, March 25. https://www.washingtonpost.com/business/2020/03/25/trump -senate-coronavirus-economic-stimulus-2-trillion/.

Publisher's Note Springer Nature remains neutral with regard to jurisdictional claims in published maps and institutional affiliations.

Xiaobing Shuai is the director of research and senior economist with Chmura Economics \& Analytics. He has been with Chmura since 2004, and conducts research in a wide range of applied economics areas. A prior senior analyst with Capital One Financial Corporation, he studied at the University of Wisconsin-Madison and obtained an M.A. in Agricultural Economics and a Ph.D. in Economics. He also serves as an adjunct professor with the University of Richmond. 
Christine Chmura is CEO and Chief Economist with Chmura Economics \& Analytics. Prior to founding Chmura Economics \& Analytics, Chris was the Chief Economist at Crestar Financial Corporation, and before that an Associate Economist at the Federal Reserve Bank of Richmond. She received her Ph.D. in Business with a major in Finance and a minor in Economics from Virginia Commonwealth University. Chris has served on the Governor's Economic Advisory Board of the Commonwealth of Virginia for the last seven governors. She also serves as an adjunct professor with the University of Richmond.
James Stinchcomb is a JobsEQ Economist with Chmura Economics \& Analytics who leads the Real-Time Intelligence (RTI) team. James has been with Chmura since 2016, and besides RTI, has worked on a number of projects, including Chmura's FedSpendTOP federal contract dataset, the development of a detailed regional and industry GDP model, and the JobsEQ Economic Impact model. He graduated from Cleveland State University in 2015 with his Master's Degree in Economics; prior to that he earned his BA in Economics from The Ohio State University. 